\title{
Increased production of carrageenase by Pseudomonas aeruginosa ZSL-2 using Taguchi experimental design
}

\author{
M. Ziayoddin ${ }^{1, *}$, Junna Lalitha ${ }^{1}$, Manohar Shinde ${ }^{2}$ \\ ${ }^{1}$ Department of Biochemistry, Gulbarga University, Gulbarga - 585106, Karnataka, India \\ ${ }^{2}$ Department of Studies and Research in Biochemistry, Tumkur University, \\ Tumkur - 572103, Karnataka, India \\ *E-mail address: ziyagug@gmail.com
}

\begin{abstract}
The culture conditions for the production of carrageenase were optimized using one-factor-at-atime method combined with orthogonal array design. With the one-factor-at-a-time method revealed optimal conditions for carrageenase production were $24 \mathrm{~h}$ of fermentation period, $28{ }^{\circ} \mathrm{C}$ incubation temperature at $\mathrm{pH} 8.0$ with $\mathrm{NaNO}_{3}$ as nitrogen source and carrageenan as carbon source in MMS media. Further optimization of carrgeenase production by using orthogonal experimental design $\mathrm{L}_{9}\left(3^{4}\right)$ with four factors, temperature, $\mathrm{pH}, \mathrm{NH}_{4} \mathrm{NO}_{3}$ and carrageenan with their relevant levels revealed optimised conditions for carrageenase production were temperature of $28{ }^{\circ} \mathrm{C}, \mathrm{pH} 8.0,2 \mathrm{~g} \mathrm{~L}^{-1} \mathrm{NaNO}_{3}$ and $2 \mathrm{~g} \mathrm{~L}^{-1}$ carrageenan. The order of the factors affecting the fermentation process was found to be temperature $>\mathrm{pH}>\mathrm{NaNO}_{3}>$ carrageenan. The temperature played a significant role on the carrageenase production. Higher carrageenase yield with activity of $0.542 \pm 0.045 \mathrm{U} \mathrm{ml}^{-1}$ was obtained in the optimised medium when compared to those of basal medium. Carrageenase hydrolysed products of carrageenan were identified by LC-ESI-MS as neocarrabiose, neocarrabiose-4 sulfate, neocarratetraose, neocarratetraose-4 sulfate, anhydrogalactose, galactose, galactose-4 sulphate and sulphate.
\end{abstract}

Keywords: Carrageenase; Pseudomonas aeruginosa ZSL-2; L 9 orthogonal array design; LC-ESI-MS

\section{INTRODUCTION}

The algal polysaccharides, also known as phycocolloids, constitute a crucial carbon source for many marine bacteria which degrade the cell wall of algae by secreting specific glycoside hydrolases [1]. Carrageenan, one of the phycocolloids is a sulfated galactan made up of linear chains of galactose and 3,6-anhydrogalactose with alternating $\alpha-(1 \rightarrow 3)$ and $\beta$ $(1 \rightarrow 4)$ linkages and further classified based on the number and the position of sulfated ester(s); $\kappa$-, $l$ - and $\lambda$-carrageenan [2]. Microbial enzymes which hydrolyse phycocolloids have drawn considerable interest. The biotechnology of enzymes and enzyme degraded products of carrageenan is still in infancy compared to that of agar, alginate, starch [3] or pectin [4]. Carrageenases which hydrolyse 1,4 linkages in carrageenan to a series of homologous, even numbered oligosaccharides [5] are useful tool for the structural analysis of the cell walls and protoplast isolation from red algae [6,7]. The sulfated carrageeno-oligosaccharides have also 
drawn considerable interest [8] owing to their diverse biological and physiological activities including anticoagulation [9], anti-inflammation [10], anti-thrombosis [11], antitumor activity [12] and viral inactivation [13], which depend on structural parameters such as carbohydrate structure, molecular mass, degree of sulfate esterification, and the linking position of sulpho groups [14].

Several bacterial genera including Pseudomonas carrageenovora [8,9], Cytophaga $[10,11]$, Alteromonas carrageenovora [12,13], Vibrio sp. [15] and Zobellia galactanovorans [16] have been reported carrageenase production one-factor-at-a-time method. Improvement of productivity of microbial metabolite by the organisms was done by manipulating the nutritional parameters, physical parameters and strain improvement [16]. Medium optimization by single dimensional search was laborious and time consuming and requires a large number of experiments to determine optimum levels, which are unreliable. Optimizing all the effecting parameters can eliminate these limitations of a single factor optimization process collectively by statistical experimental design. Several statistical factorial designs ranging from two-factorial to multi-factorial designs are available for optimization of process parameters $[17,18]$. Taguchi method is a popular experimental design currently applied in industries for optimization serves as screening filters that examine the effects of many process variables and identify those factors that have major effects on process by using a few experiments.

Previously we have reported the optimization of production conditions for carrageenase by solid state fermentation of Pseudomonas aeruginosa ZSL-2 [19]. In present investigation we report establishment of culture conditions for the production of extracellular carrageenase by SmF of Pseudomonas aeruginosa ZSL-2 using one-factor-at-a-time method by changing one of the independent variables, temperature, $\mathrm{pH}$ etc. while fixing the others at certain levels and $\mathrm{L}_{9}\left(3^{4}\right)$ design was applied to screen the significant factors according to preliminary experiments. The analysis of carrageenan degraded products by LC-ESI-MS is also carried out.

\section{MATERIALS AND METHODS}

\section{1. Bacterial strain and culture conditions}

One of the agarolytic bacteria isolated from marine water Pseudomonas aeruginosa ZSL-2 capable of utilizing both agar and carrageenan [20] was selected for further studies and stored at $4{ }^{\circ} \mathrm{C}$ on minimal mineral salts (MMS)-agar slants. The bacterium was routinely grown on MMS medium with agar as energy source at $37^{\circ} \mathrm{C}$. Seed culture was prepared from $24 \mathrm{~h}$ grown cultures on MMS liquid broth at $180 \mathrm{rpm}$ and $37^{\circ} \mathrm{C}$.

\section{2. Culture conditions for acclimatization to carrageenan}

The fermentation medium composed g.L $\mathrm{L}^{-1} ; \mathrm{K}_{2} \mathrm{HPO}_{4}, 0.38 ; \mathrm{MgSO}_{4}, 0.20 ; \mathrm{FeCl}_{3}, 0.05$; $\mathrm{NH}_{4} \mathrm{NO}_{3}, 1.0 ; \mathrm{pH} 8.0$ was supplemented with carrageenan $(0.3 \%)$ as the only source of carbon. The bacterial seed culture was used for inoculation. The cultures were maintained on minimal salts agar $(1.5 \%)$ and carrageenan $(0.5 \%)$ plate or slants, or LB agar $(1.5 \%)$ and carrageenan $(0.5 \%)$ plate or slants and sub cultured fortnightly.

\section{3. Assay of carrageenase activity}

The carrageenase activity was determined by neocuproine method as described by Dygert et al [21]. The assay mixture $1 \mathrm{ml}$ contained $20 \mathrm{mM}$ Tris- $\mathrm{HCl}$ buffer $(\mathrm{pH} 8.0), 0.5 \mathrm{ml}$ 
of carrageenan $(0.1 \% \mathrm{w} / \mathrm{v}$ in Tris- $\mathrm{HCl}$ buffer $)$ and $50 \mu 1$ suitably diluted enzyme at $40{ }^{\circ} \mathrm{C}$. For carrageenase assay it was necessary to add ethanol $(50 \%, \mathrm{v} / \mathrm{v})$ to reaction mixture before measuring the absorbance.

One unit of the enzyme activity was defined as the amount which liberates $1 \mu \mathrm{mol}$ galactose equivalent per minute under assay conditions. The protein content of the enzyme solution was determined according to Lowry et al [22].

\section{4. Optimization of culture conditions for carrageenase production}

The optimization of fermentation conditions and medium compositions were carried out based on the stepwise modification of the governing parameters for carrageenase production. They include fermentation period, $\mathrm{pH}$, temperature, $\mathrm{NaCl}$, carbon source and nitrogen sources. The optimum culture conditions obtained in previous step were used in next step.

The $P$. aeruginosa ZSL-2 was inoculated into the MMS medium supplemented with carrageenan $(0.3 \% \mathrm{w} / \mathrm{v})$ and incubated. A $1 \mathrm{ml}$ exponential growth phase culture was inoculated into a fresh $250 \mathrm{ml}$ Erlenmeyer flask containing $50 \mathrm{ml}$ MMS medium supplemented with carrageenan $(0.3 \% \mathrm{w} / \mathrm{v})$.

The growth of the bacterium and carrageenase production in culture supernatants were analysed at different incubation periods. The effect of incubation temperature was determined by incubating the bacterium at different temperature ranging from 20 to $40^{\circ} \mathrm{C}$, at $\mathrm{pH} 8.0$ after $24 \mathrm{~h}$. Similarly, influence of medium $\mathrm{pH}$ was determined from $\mathrm{pH} 5$ to 10 at $28^{\circ} \mathrm{C}$. The effect of $\mathrm{NaCl}$ on the growth and enzyme production was determined by incubating at $28{ }^{\circ} \mathrm{C}$ for 24 $\mathrm{h}$ with $\mathrm{NaCl}$ in MMS medium at $\mathrm{pH}$ 8.0.

To study the effect of different nitrogen sources on carrageenase production, $\mathrm{NH}_{4} \mathrm{NO}_{3}$ in the medium was replaced with different organic nitrogen sources $(0.1 \%, \mathrm{w} / \mathrm{v})$ such as, peptone, yeast extract, beef extract, and inorganic nitrogen sources $\left(1 \%\right.$, w/v) such as, $\mathrm{KNO}_{3}$, $\mathrm{NH}_{4} \mathrm{Cl}, \mathrm{NaNO}_{3},\left(\mathrm{NH}_{4}\right)_{2} \mathrm{SO}_{4}$ and fermentation was carried out as described earlier.

The influence of carbon source on the carrageenase production was analysed by growing $P$. aeruginosa ZSL-2 in the MMS medium supplemented with various carbon sources $(0.2 \%$ to $0.5 \%, \mathrm{w} / \mathrm{v})$ such as glucose, galactose, fructose, lactose, sucrose, mannose, maltose and carrageenan alone or the said carbon sources were co-supplemented with carrageenan.

\section{5. Orthogonal test (Taguchi method)}

Based on the one-factor-at-a-time method, an $\mathrm{L}_{9}\left(3^{4}\right)$ orthogonal array method was used to determine the optimal medium conditions for carrageenase production. This enables to determine the process variables affecting the response.

The level-setting values of the factors used in the orthogonal array design are shown in Table 4. The four variables, carrageenan, $\mathrm{NaNO}_{3}$, temperature and $\mathrm{pH}$ with three concentration levels were used. The experiments were carried out in $250 \mathrm{ml}$ Erlenmeyer flasks containing $50 \mathrm{ml}$ MMS medium. The carrageenase activity of each flask was assayed after $24 \mathrm{~h}$ of incubation and analysed statistically by ANOVA.

\section{6. LC-ESI-MS analysis of carrageenan oligosaccharides}

The hydrolysed products of carrageenan by $P$. aeruginosa ZSL-2 supplemented in the growth medium were analyzed by LC-ESI-MS as reported by Baswaraj et al., [23]. Briefly; a 
$1 \mathrm{ml}$ of the culture medium was withdrawn, cooled to $4{ }^{\circ} \mathrm{C}$ and centrifuged for $15 \mathrm{~min}$ at $14,000 \mathrm{rpm}$ at $4{ }^{\circ} \mathrm{C}$. A $500 \mu \mathrm{l}$ of clarified culture supernatant was extracted by $80 \%$ methanol $\left(-20^{\circ} \mathrm{C}\right)$ and evaporated to dryness by a vacuum manifold.

The residue was then re-dissolved in $100 \mu \mathrm{l}$ of $80 \%$ methanol and was filtered through a $5 \mathrm{kDa}$ centricon filter and the filtrate obtained was transferred to an autosampler vial. Ten microliters of cuture supernatant filtered through $0.22 \mu$ syringe filter was injected through auto sampler into a $150 \mathrm{~mm} \times 4 \mathrm{~mm}$ i.d, $5 \mu$ phenomenex, C-18, RP-column (thermostated at $40{ }^{\circ} \mathrm{C}$ ) at flow rate $1 \mathrm{ml} \mathrm{min}^{-1}$.

LC is synchronized with mass Q TRAP 4000 MS-MS (Applied Biosystems MDSSCIX). LC-ESI-MS data acquisition was carried out at $22 \mathrm{~min}$. EMS spectra were generated from the TIC. Spectra were recorded in negative mode between $\mathrm{m} / \mathrm{z} 50$ and 1200 . Identification was carried out with AB's Analyst 1.2.2 software.

\section{RESULTS}

\section{1. Optimization of culture parameters for carrageenase production from Pseudomonas aeruginosa ZSL-2 by "one-factor-at-a-time" (OFAT)}

The effect of different culture parameters viz., fermentation period, temperature, optimum $\mathrm{pH}$ of fermentation medium, ionic strength and carbon and nitrogen sources, on the growth of $P$. aeruginosa ZSL-2, and production of extracellular carrageenase was investigated.

The growth of the bacterium at different incubation periods was determined by monitoring the change in the absorbance at $660 \mathrm{~nm}$ and the carrageenase activity in the fermentation broth was assayed simultaneously. It was observed that, the growth of the bacterium was increased with the increase in the incubation time. The carrageenase production by $P$. aeruginosa ZSL-2, was observed after $12 \mathrm{~h}$ of incubation, which increased with an increase in the incubation period.

Maximum carrageenase activity $(0.257 \mathrm{U} / \mathrm{ml})$ was observed in late log phase at $24 \mathrm{~h}$ incubation, thereafter the carrageenase production decreased (Fig. 1). The bacterium was able to grow at temperatures ranging from 25 to $40{ }^{\circ} \mathrm{C}$, maximum carrageenase production $(0.311$ $\mathrm{U} / \mathrm{ml}$ ) was observed at $28^{\circ} \mathrm{C}$ (Fig. 2). P. aeruginosa ZSL-2 grew in a broad range of $\mathrm{pH} 5.0$ 11.0. showed good growth at $\mathrm{pH}$ range from 7.0-10.0; however, the maximal carrageenase production $(0.355 \mathrm{U} / \mathrm{ml})$ was observed when grown at $\mathrm{pH} 8.0$ (Fig. 3).

The effect of sodium chloride on the growth of the microorganism in the fermentation medium was studied with the amendment of carrageenan $(0.3 \%, \mathrm{w} / \mathrm{v})$ at $\mathrm{pH} 8$, temperature $28{ }^{\circ} \mathrm{C}$ It is evident that the microorganism grew in presence of sodium chloride ( 0 to $5 \%$ ). The maximal growth appeared at $1 \% \mathrm{NaCl}$.

The organism did not show a specific requirement of sodium chloride and grew even at 0-2 \% levels of sodium chloride. The carrageenase production was found to be slightly increased with increase in the concentration of $\mathrm{NaCl}$ up to $1 \%(\mathrm{w} / \mathrm{v})$, beyond which there was sharp decline in the secretion. At $4 \% \mathrm{NaCl}$, the carrageenase activity was not detected though the organism was able to grow (Fig. 4). 


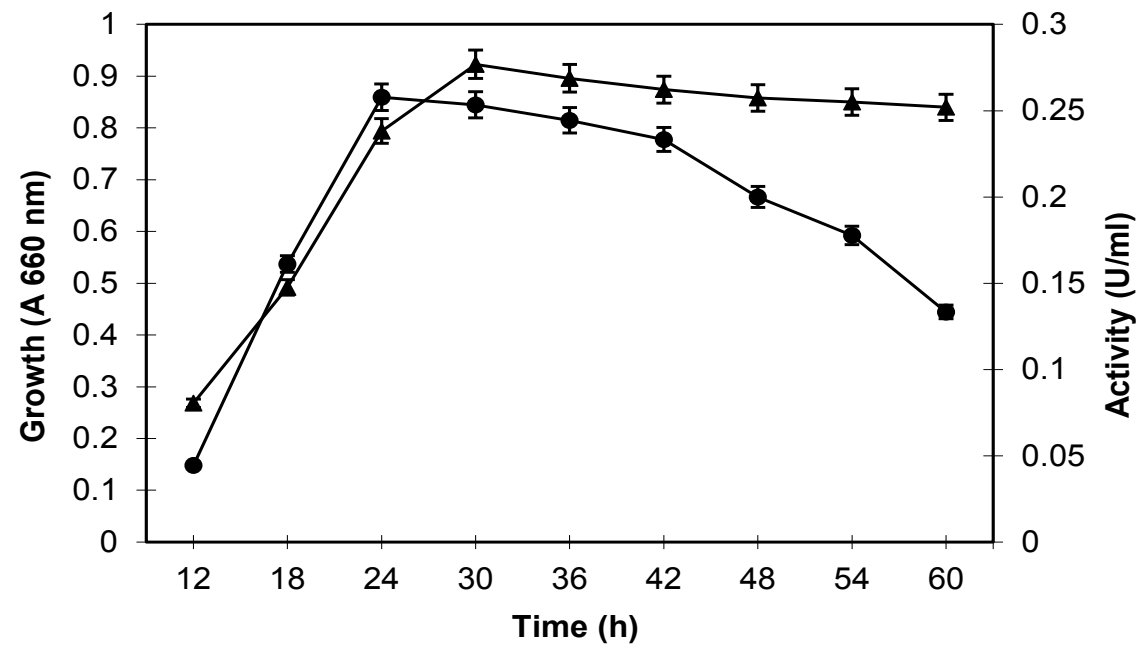

Fig. 1. Effect of incubation time on the growth of Pseudomonas aeruginosa ZSL-2 ( $\mathbf{\Delta})$ and the production of extracellular carrageenase $(\bullet)$.

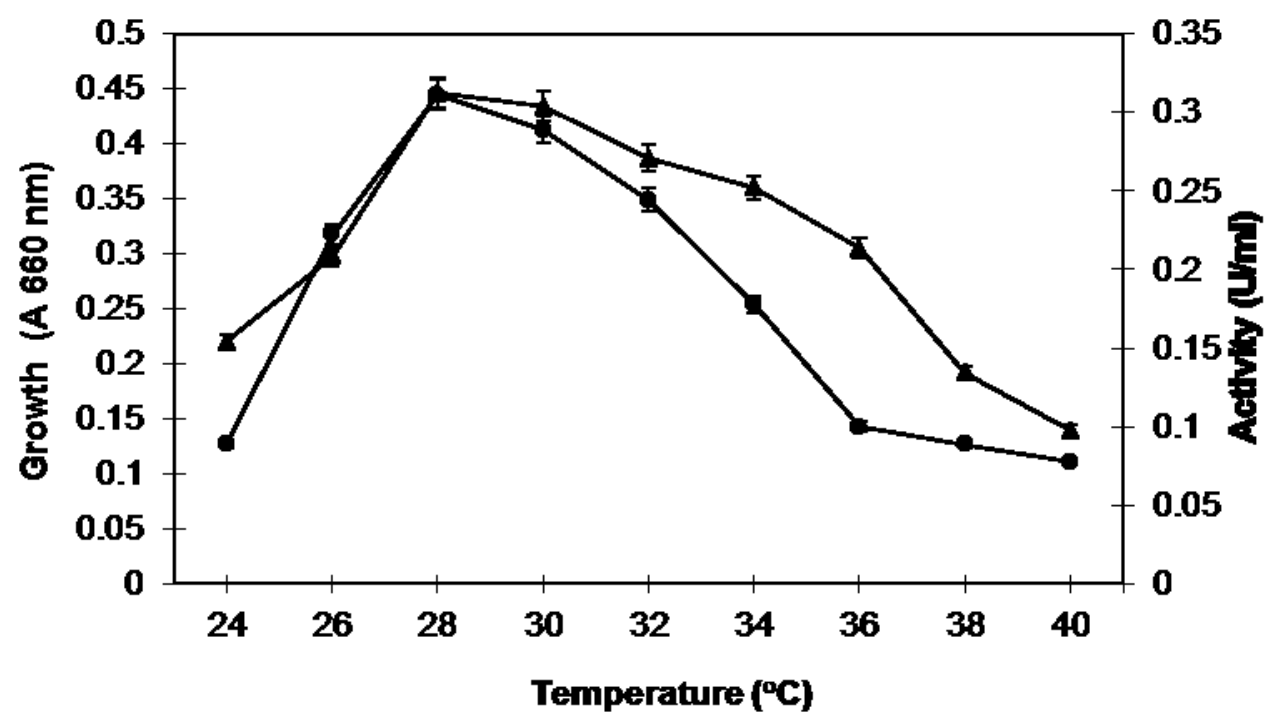

Fig. 2. Effect of temperature on the growth of Pseudomonas aeruginosa ZSL-2 ( $\mathbf{\Delta})$ and the activity of of extracellular carrageenase $(\bullet)$. 


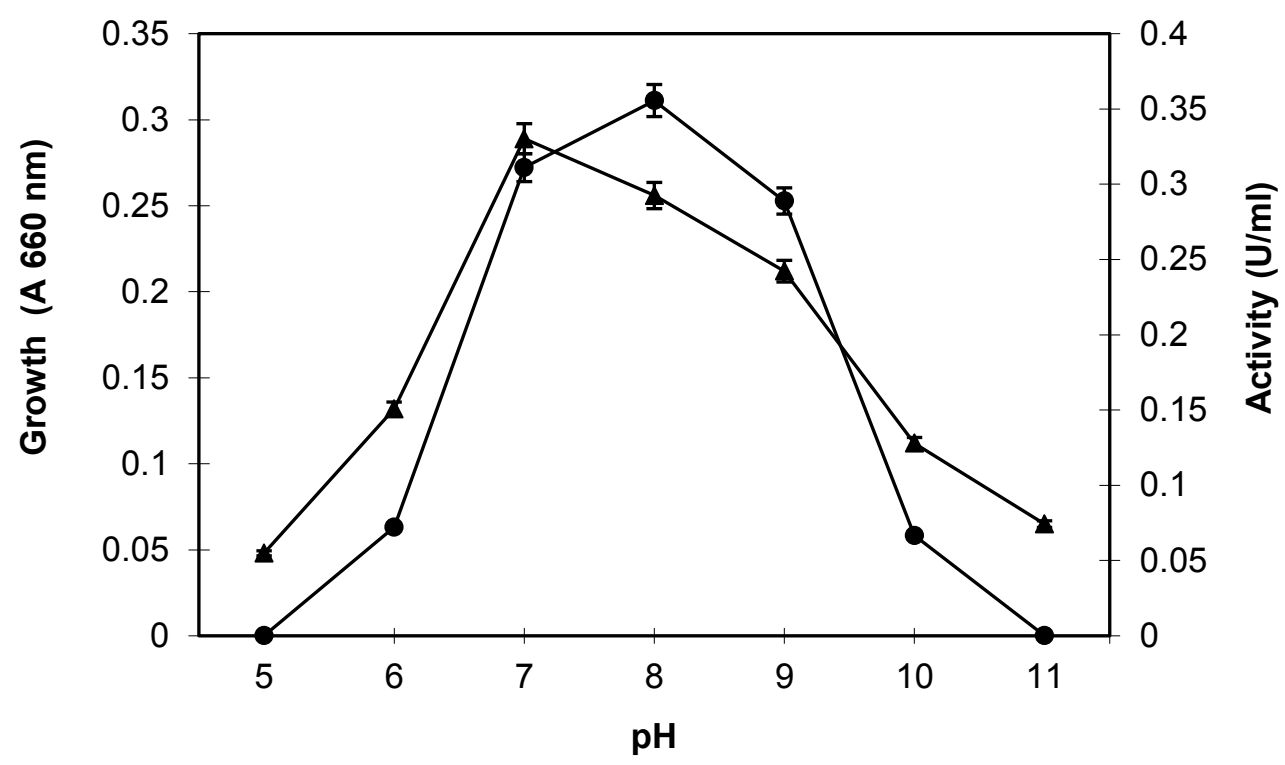

Fig. 3. Effect of media $\mathrm{pH}$ on growth $(\boldsymbol{\Delta})$ and production $(\bullet)$ of extracellular carrageenase by Pseudomonas aeruginosa ZSL-2.

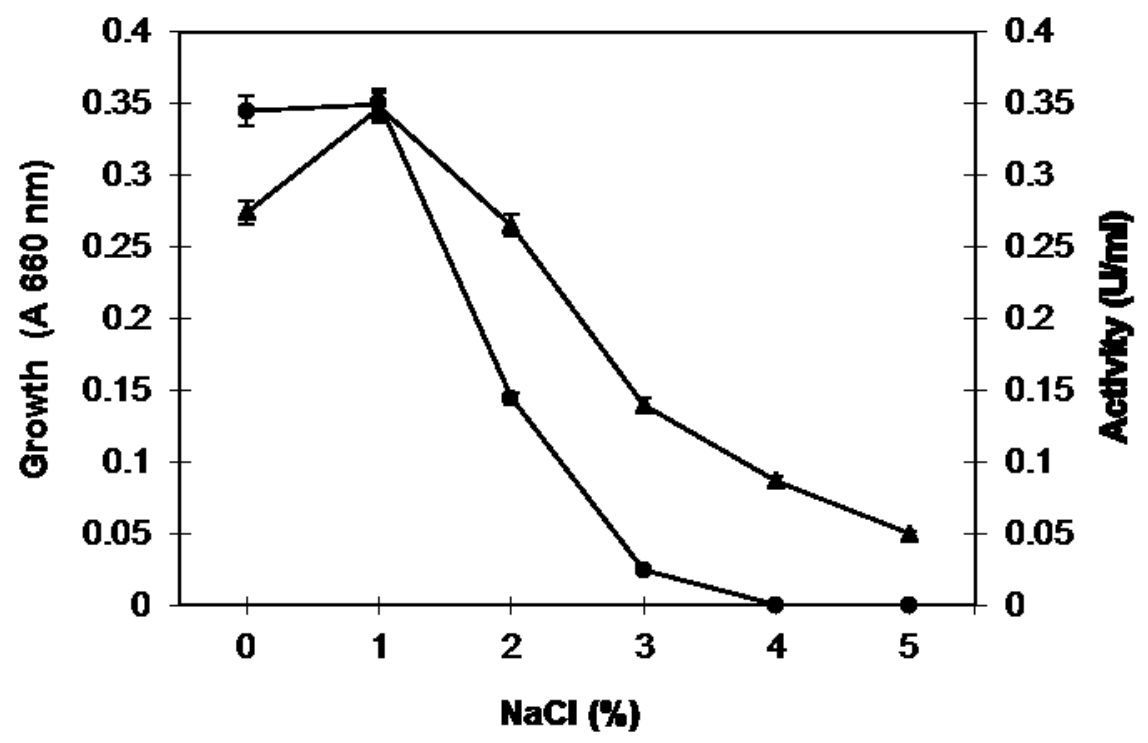

Fig. 4. Effect of $\mathrm{NaCl}$ on growth $(\boldsymbol{\Delta})$ and production $(\bullet)$ of extracellular carrageenase by Pseudomonas aeruginosa ZSL-2.

The growth of the bacterium was found to be optimum in the medium supplemented with $\mathrm{NaNO}_{3}$ or $\mathrm{NH}_{4} \mathrm{NO}_{3}$ as nitrogen source and carrageenan as the carbon source. The production of carrageenase was found to maximum $(0.393 \mathrm{U} / \mathrm{ml})$ in the medium, which had received $\mathrm{NaNO}_{3}$ as nitrogen source. The production of carrageenase was found to be less in the fermentation medium, containing organic nitrogen sources. 
However, peptone served as a good source of nitrogen and supported luxuriant growth however carrageenase production was found to be less (Table 1).

Table 1. Effect of nitrogen source on the growth and production of carrageenase by Pseudomonas aeruginosa ZSL-2.

\begin{tabular}{ccc}
\hline Nitrogen source* & $\begin{array}{c}\text { Growth } \\
\left(\mathbf{A}_{660 n m}\right)\end{array}$ & $\begin{array}{c}\text { Carrageenase } \\
\text { activity (U/mI) }\end{array}$ \\
\hline $\mathrm{NH}_{4} \mathrm{NO}_{3}$ & 0.317 & 0.288 \\
$\mathrm{KNO}_{3}$ & 0.284 & 0.222 \\
$\mathrm{NH}_{4} \mathrm{Cl}$ & 0.275 & 0.094 \\
$\mathrm{NaNO}_{3}$ & 0.297 & 0.393 \\
$\left(\mathrm{NH}_{4}\right)_{2} \mathrm{SO}_{4}$ & 0.206 & 0.166 \\
Peptone & 0.273 & 0.177 \\
Yeast extract & 1.111 & 0.100 \\
Beef extract & 0.902 & 0.088
\end{tabular}

* Fermentation conditions: MMS media containing one of the nitrogen source, supplemented with carrageenan at $\mathrm{pH} 8$, temperature $28^{\circ} \mathrm{C}$ after $24 \mathrm{~h}$ of incubation

The $P$. aeruginosa ZSL-2 utilized various other organic chemicals as carbon source. carrageenase production was observed in the fermentation media supplemented with carrageenan. The organism grew well utilizing other simple sugars, while carrageenase production was not observed (Table 2). On the other hand carrageenase production was observed when simple sugars were co-supplemented to carrageenan containing fermentation media. The results revealed that carrageenase production was inducible only in presence of carrageenan and co-supplementation of other simple sugars found to decrease the production slightly.

Table 2. Effect of carbon sources on growth and production of extracellular carrageenase by Pseudomonas aeruginosa ZSL-2.

\begin{tabular}{cccccc}
\hline $\begin{array}{c}\text { Carbon } \\
\text { source }\end{array}$ & $\begin{array}{c}\text { Growth } \\
\left(\mathbf{A}_{660 \mathrm{~m}}\right)\end{array}$ & $\begin{array}{c}\text { Carrageenase } \\
\text { production } \\
\mathbf{( U / m )}\end{array}$ & $\begin{array}{c}\text { Co- } \\
\text { Supplimentation } \\
\text { of sugars * }\end{array}$ & $\begin{array}{c}\text { Growth } \\
\left(\mathbf{A}_{660 \mathrm{~nm}}\right)\end{array}$ & $\begin{array}{c}\text { Carrageenase } \\
\text { production } \\
(\mathbf{U} / \mathbf{~ m l})\end{array}$ \\
\hline Carrageenan & 0.382 & 0.3444 & $\mathrm{C}$ alone & 0.342 & 0.322 \\
Fructose & 1.02 & 0.0174 & $\mathrm{C}+$ Fructose & 0.402 & 0.277 \\
Glucose & 1.175 & $\mathrm{ND}$ & $\mathrm{C}+$ Glucose & 0.475 & 0.305 \\
Galactose & 1.035 & $\mathrm{ND}$ & $\mathrm{C}+$ Lactose & 0.711 & 0.233 \\
Lactose & 0.911 & 0.0054 & $\mathrm{C}+$ Sucrose & 0.236 & 0.222 \\
Sucrose & 0.836 & 0.003 & $\mathrm{C}+$ Mannose & 0.298 & 0.244 \\
\hline
\end{tabular}




\begin{tabular}{cccccc}
\hline Mannose & 0.928 & 0.0092 & $\mathrm{C}+$ Galactose & 0.335 & 0.300 \\
Maltose & 1.247 & 0.0109 & $\mathrm{C}+$ Maltose & 0.547 & 0.238 \\
\hline
\end{tabular}

ND-Not detected C- Carrageenan

* Equal quantities of carrageenan and co-supplemented sugar were added to the media

\section{2. Experimental results of $\mathrm{L}_{9}\left(3^{4}\right)$ orthogonal matrix method}

The optimal conditions for the culture process were obtained by using orthogonal design $\mathrm{L}_{9}\left(3^{4}\right)$ based on one-factor-at-time method (Table 3). The effects of these factors on carrageenase production were analyzed statistically and results are shown in Table 4.

The optimum culture conditions obtained from the statistical analysis were at temperature of $28^{\circ} \mathrm{C}$, $\mathrm{pH} 8.0,2 \mathrm{gL}^{-1} \mathrm{NaNO}_{3}$ and carrageenan $2 \mathrm{gL}^{-1}$. Similarly, the order of effect of factors affecting the fermentation process was found to be; temperature $>\mathrm{pH}>$ $\mathrm{NaNO}_{3}>$ carrageenan. According to the interaction among the tested factors, the temperature had significant effect on the carrageenase production (Table 5). The validation experiments were conducted to obtain the maximum yields of carrageenase using the above optimal culture conditions. The carrageenase activity, $0.542 \mathrm{U} / \mathrm{ml}$ was obtained which was much higher than those in basal culture media, suggests that the carrageenase production has been further improved with orthogonal experiment design.

Table 3. Factors and their levels employed in the $\mathrm{L}_{9}\left(3^{4}\right)$ in OATS for production of carrageenase by submerged fermentation of $P$. aeruginosa ZSL-2.

\begin{tabular}{|c|c|c|c|c|}
\hline Factors & $\begin{array}{c}\mathbf{A} \\
\mathbf{T e m p} \\
\left(\mathbf{C}^{\mathbf{0}} \mathbf{C}\right)\end{array}$ & $\begin{array}{c}\mathbf{B} \\
\mathbf{p H}\end{array}$ & $\begin{array}{c}\mathbf{C} \\
\mathbf{N i t r o g e n} \\
\mathbf{( g} \cdot \mathbf{L}^{-\mathbf{1}} \mathbf{)}\end{array}$ & $\begin{array}{c}\mathbf{D} \\
\mathbf{C a r b o n} \\
\mathbf{( g} \cdot \mathbf{L}^{-\mathbf{1}} \mathbf{)}\end{array}$ \\
\hline level 1 & 28 & 7.5 & 1 & 1 \\
\hline level 2 & 30 & 8.0 & 2 & 2 \\
\hline level 3 & 32 & 8.5 & 3 & 3 \\
\hline
\end{tabular}

Table 4. $\mathrm{L}_{9}\left(3^{4}\right)$ Orthogonal array testing strategy (OATS) method for optimization of fermentation parameters for carrageenase production by submerged fermentation of $P$. aeruginosa ZSL-2.

\begin{tabular}{ccccccc}
\hline S. No. & $\mathbf{A}$ & $\mathbf{B}$ & $\mathbf{C}$ & $\mathbf{D}$ & \multicolumn{2}{c}{$\begin{array}{c}\text { Carrageenase activity } \\
(\mathbf{U} / \mathbf{m l})\end{array}$} \\
\hline 1 & $1\left(28^{\circ} \mathrm{C}\right)$ & $1(\mathrm{pH} \mathrm{7.5)}$ & 1 & 1 & 0.342 & \pm 0.010 \\
2 & $1\left(28^{\circ} \mathrm{C}\right)$ & $2(\mathrm{pH} 8.0)$ & 2 & 2 & 0.520 & \pm 0.015 \\
3 & $1\left(28^{\circ} \mathrm{C}\right)$ & $3(\mathrm{pH} 8.5)$ & 3 & 3 & 0.377 & \pm 0.011 \\
\hline
\end{tabular}




\begin{tabular}{ccccccc}
\hline 4 & $2\left(30{ }^{\circ} \mathrm{C}\right)$ & $1(\mathrm{pH} .5)$ & 2 & 3 & 0.244 & \pm 0.007 \\
5 & $2\left(30{ }^{\circ} \mathrm{C}\right)$ & $2(\mathrm{pH} .0)$ & 3 & 1 & 0.210 & \pm 0.006 \\
6 & $2\left(30{ }^{\circ} \mathrm{C}\right)$ & $3(\mathrm{pH} 8.5)$ & 1 & 2 & 0.156 & \pm 0.004 \\
7 & $3\left(32{ }^{\circ} \mathrm{C}\right)$ & $1(\mathrm{pH} 7.5)$ & 3 & 2 & 0.128 & \pm 0.003 \\
8 & $3\left(32{ }^{\circ} \mathrm{C}\right)$ & $2(\mathrm{pH} 8.0)$ & 1 & 3 & 0.132 & \pm 0.003 \\
9 & $3\left(32{ }^{\circ} \mathrm{C}\right)$ & $3(\mathrm{pH} 8.5)$ & 2 & 1 & 0.068 & \pm 0.002 \\
${ }^{\mathrm{a}} K 1$ & 1.239 & 0.714 & 0.63 & 0.62 & & \\
$K 2$ & 0.61 & 0.862 & 0.832 & 0.804 & & \\
$K 3$ & 0.328 & 0.601 & 0.715 & 0.753 & & \\
${ }^{\mathrm{b}} k 1$ & $\mathbf{0 . 4 1 3}$ & 0.238 & 0.21 & 0.206 & & \\
$k 2$ & 0.203 & $\mathbf{0 . 2 8 7}$ & $\mathbf{0 . 2 7 7}$ & $\mathbf{0 . 2 6 8}$ & & \\
$k 3$ & 0.109 & 0.200 & 0.238 & 0.251 & & \\
${ }^{\mathrm{c}} \Delta$ & 0.303 & 0.087 & 0.067 & 0.061 & & \\
$R$ & 1 & 2 & 3 & 4 & & \\
Opt & $\mathrm{A}_{1}$ & $\mathrm{~B} 2$ & $\mathrm{C}_{2}$ & $\mathrm{D}_{2}$ & &
\end{tabular}

The assignments of column A, B, C, and D were performed by orthogonal array consisted of nine experiments corresponding to the nine rows and four columns.

${ }^{\mathrm{a}} k_{i}=\sum k$ of all experiment at the same factor level.

${ }^{\mathrm{b}}$ Average of $k_{\mathrm{i}}$.

${ }^{\mathrm{c}} \Delta=\max \left\{\right.$ average of $\left.k_{i}\right\}-\min$ average of $\left.k_{i}\right\}$.

Values are mean of triple determinations with standard deviation $( \pm)$.

Opt - optimization

Table 5. ANOVA of $\mathrm{L}_{9}\left(3^{4}\right)$ Orthogonal array testing strategy (OATS) for optimization of fermentation parameters for carrageenase production by submerged fermentation of $P$. aeruginosa ZSL-2.

\begin{tabular}{ccccccc}
\hline & $\begin{array}{c}\text { Sum of } \\
\text { squares }\end{array}$ & df & $\begin{array}{c}\text { Mean of } \\
\text { square }\end{array}$ & $\boldsymbol{F}$ value & Critical value & Significance \\
\hline Temperature & 0.0483 & 2 & 0.0241 & 3.4249 & $F_{0.10}(2,8)=3.113$ & $*$ \\
$\mathrm{pH}$ & 0.0038 & 2 & 0.0019 & 0.2701 & \\
Nitrogen & 0.0022 & 2 & 0.0011 & 0.1623 & \\
Carbon & 0.0020 & 2 & 0.0010 & 0.1425 & \\
Error & 0.0564 & 8 & 0.0070 & & & \\
\hline
\end{tabular}




\section{3. LC-ESI-MS analysis of carrageenan hydrolysed products}

The presence of oligosaccharides ranging from mono- to hexa- carrageenan were identified based on signals observed at $\mathrm{m} / \mathrm{z} 161,179$ and 79 , which corresponds to the anhydrogalactose, desulfated galactose and sulfate, respectively (Table 6). The signals observed at $\mathrm{m} / \mathrm{z} 259.1,323,403,629.9$ and 788.8 were corresponding to galactose- 4 sulphate, neocarrabiose, neocarrabiose-4 sulfate, neocarratetraose and neocarratetraose-4 sulfate, respectively. The carrageenase secreted by $P$. aeruginos a ZSL-2, thus acted as endo-enzymes and capable of hydrolysing carrageenan into mainly tetrose, biose and then to monomers.

Table 6. LC-ESI-MS spectrometry analysis of carrageenase hydrolyzed products of carrageenan in culture supernatant by $P$. aeruginosa ZSL-2 grown for $24 \mathrm{~h}$.

\begin{tabular}{cc}
\hline $\begin{array}{c}\text { Carrageenana } \\
\text { oligosaccharide }\end{array}$ & $\mathbf{m} / \mathbf{z}$ \\
\hline$\left[\mathrm{G}_{4} \mathrm{~S}\right]$ & 259.1 \\
{$[\mathrm{DA}-\mathrm{G}]$} & 323.0 \\
{$\left[\mathrm{DA}-\mathrm{G}_{4} \mathrm{~S}\right]$} & 403.0 \\
{$\left[\mathrm{DA}-\mathrm{G}_{2}\right.$} & 629.9 \\
{$\left[\mathrm{DA}-\mathrm{G}_{4} \mathrm{~S}_{2}\right.$} & 788.8 \\
{$\left[\mathrm{SO}_{3}{ }^{-}\right]$} & 79 \\
{$[\mathrm{DA}]$} & 161.1 \\
{$[\mathrm{G}]$} & 179.1 \\
\hline
\end{tabular}

DA - anhydrogalactose, G - Galactose, $\mathrm{G}_{4} \mathrm{~S}$ - Galactose 4 sulphate, DA-G - neocarrabiose, DA-G 4 S - neocarrabiose 4 sulfate, $[D A-G]_{2}-$ neocarratetraose,

$\left[\mathrm{DA}-\mathrm{G}_{4} \mathrm{~S}\right]_{2}$ - neocarratetraose 4 sulfate, and $\mathrm{SO}_{3}{ }^{-}$sulphate ions.

\section{DISCUSSION}

The optimum $\mathrm{pH}$ and temperature for carrageenase production were around $\mathrm{pH} 8$ and 28 ${ }^{\circ} \mathrm{C}$, respectively, and this is because the isolated strian had adapted to the alkaline and low temperature marine environment for the growth. The $\mathrm{pH}$ of the culture strongly affects enzymatic processes and transport of compounds across the cell membrane. Several carrageenan degrading bacteria Pseudomonas elongata [24], Cytophaga sp. [25], Cytophaga like bacterium [26-28] were found to produce carrageenases at $\mathrm{pH}$ range of 7-8 and few at different temperatures, ranging from $25{ }^{\circ} \mathrm{C}[15,29]$ to $37{ }^{\circ} \mathrm{C}[24,27]$ are reported. The $P$. aeruginosa ZSL-2 grows better, when the growth medium was supplemented with $1 \%$ sodium chloride. It grew nearly optimal even in the absence of sodium chloride. It is commonly assumed that marine bacteria live in the sea, most of them are salt tolerant. Most carrageenan utilizing bacteria like P. elongata [24], P. alteromonas-like bacterium WZUC10 
[30], P. carrageenovora [7,31], Vibrio sp. CA-1004 [15] and Cytophaga sp [26] isolated from marine sources are reported to have a specific requirement of sodium chloride for their growth. The $P$. aeruginosa ZSL-2 grows better at $1 \% \mathrm{NaCl}$ concentration and unlike other carrageenolytic marine bacterium $P$. aeruginosa ZSL-2 do not demand for sodium chloride as a specific requirement, more over, even in its absence, the organism could grew well and produces extracellular carrageenase. An understanding of the influence of nitrogen source on the growth of $P$. aeruginosa ZSL-2 was derived by growing the later in the fermentation medium containing one of the nitrogen sources and supplemented with carrageenan $(0.3 \%$, $\mathrm{w} / \mathrm{v}$ ) as sole carbon source. The observed results indicated that $\mathrm{NaNO}_{3}$ as a sole nitrogen source supported the optimum growth and maximum enzyme production, thus nitrogen was found to be an essential element for the production of the carrageenase.

All the simple sugars tested were utilized as carbon sources for the growth of the $P$. aeruginosa ZSL-2.carrageenase production was observed when ti was grown on th carrageenan as carbon source and also in co-supplemented with other carbon sources. When simple sugars alone were included in the medium, although good growth was observed, carrageenase production was not occurred in the medium. This explains that the carrageenase production was inducible only in presence of carrageenan and co-supplementation of other simple sugars found to decrease the production slightly. Catabolite repression of carrageenase production was observed in $P$. aeruginosa ZSL-2, in which carrageenase production was repressed when other carbon sources were supplemented to carrageenan. Similar observations were reported in agarase production by P. aeruginosa AG-LSL11 [32], Alteromonas Sp. (049/1) and Cytophaga saccharophila (024), in which the enzyme production was repressed by glucose, co-supplemented with agar [33]. While increased growth was observed in the medium co-supplemented with glucose, fructose or maltose. This may be due to rapid utilization of these simple sugars by the bacterium resulting in an increase in cell mass by vigorous growth. However, carrageenase production was found to be reduced.

The results with the one-factor-at-a-time method revealed that optimal conditions for the production of carrageenase were $24 \mathrm{~h}$ of fermentation period, $28{ }^{\circ} \mathrm{C}$ incubation temperature at $\mathrm{pH} 8.0$ with $\mathrm{NaNO}_{3}$ as nitrogen source and carrageenan as carbon source in MMS media. Among these four factors, temperature, $\mathrm{pH}, \mathrm{NH}_{4} \mathrm{NO}_{3}$ and carrageenan with their relevant levels are selected for further optimization of carrgeenase production by using orthogonal experimental design $\mathrm{L}_{9}\left(3^{4}\right)$. The one-factor-at-a-time (single factor) experiments enable us to determine which process variables affect the response. A logical next step is to determine the point in the important factors that leads to the best possible response with maximum production of the enzyme [34,35]. The Latin square used to optimize the nutrimental factors was $\mathrm{L}_{9}\left(3^{4}\right)$, where $\mathrm{L}_{9}$ indicates a Latin square with nine combinations of variables and $\left(3^{4}\right)$ denotes four factors with three levels. Appropriately selecting the factor one can improve the quality of the product.

The optimum culture conditions obtained from the statistical analysis were at temperature of $28{ }^{\circ} \mathrm{C}, \mathrm{pH} 8.0,2 \mathrm{gL}^{-1} \mathrm{NaNO}_{3}$ and carrageenan $2 \mathrm{gL}^{-1}$. The order of effect of four factors on carrageenase production was temperature $>\mathrm{pH}>\mathrm{NaNO}_{3}>$ carrageenan. According to the interaction among the tested factors, the temperature had significant effect on the carrageenase production. The validation experiments were conducted to obtain the maximum yields of carrageenase using the above optimal culture conditions. The carrageenase activity, $0.542 \mathrm{U} / \mathrm{ml}$ was obtained which was much higher than those in basal culture media, suggests that the carrageenase production has been further improved with orthogonal experiment design. The orthogonal array design technique that has been successfully applied for the improvement of culture conditions of fermentation process to 
provide the relationships among various factors, and the order of significant factors for the optimum results [4,19,36,37].

The electrospray ionization mass spectrometry (ESI-MS) technique was employed for the analysis of carrageenan hydrolysed oligosaccharides samples. The ESI-MS analysis of the culture supernatants of $P$. aeruginosa ZSL-2 revealed that commercial carrageenan was hydrolyzed initially by the action of extracellular carrageenase to oligosaccharides ranging from mono- to tetra-carrageenan oligosaccharides. ESI-MS creates multiple charged ions making the interpretation of a mixture of highly charged oligosaccharides through direct ESIMS analysis a rather complex task [38,39]. This has been demonstrated for the first time for the characterization of enzymaticaly digested correspondent $\kappa$ - and 1 -carrageenan using LC/ESI-MS method, which is based on ion pair liquid chromatography coupled with ESI-MS in the negetive-ion mode. This method can directly determine and verify the exact number of sulphate groups, as well as the molecular weight of the primary backbone structure of each oligosaccharide in the mixture.

\section{CONCLUSION}

Using the one-factor-at-a-time method and orthogonal matrix design, it was possible to determine optimal conditions to obtain maximum yield of carrageenase. Two optimization techniques used in this work can be widely applied to other processes for optimization of submerged culture conditions for production of other enzymes. The P. aeruginosa ZLS-2 could be used for the production of biotechnologically important, commercial, alkali active enzymes for their industrial applications.

\section{ACKNOWLEDGEMENTS}

This work was supported in part by research grant from Department of Science and Technology (DST), New Delhi, India (Project No. 100/IFD/5186/2007-2008 dated 6/11/2007). M. Ziayoddin is grateful to UGC New Delhi, India for research fellowship (MANF JRF (No.F.40-49(M)/2009(SA-III/MANF) dated 08 Jan 2011). The authors thank Gulbarga University, Gulbarga for laboratory facility.

\section{References}

[1] Michel G., Nyval-Collen P., Barbeyron T., Czjzek M., Helbert W., Appl Microbiol Biotechnol. 71 (2006) 23-33.

[2] Knutsen S., Myslabodski D., Larsen B., Usov A., Bot Mar. 37 (1994) 163-169.

[3] Guzman-Maldonado H., Paredes-Lopez O., Critical Review in Food Science Nutrition 35 (1995) 373-403.

[4] Beldman G, Mutter M, Searle-van Leeuwen MJF, van den Broek LAM, Schols HA, Voragen AGJ. Visser J, \& Voragen, A.G.J. Amsterdam: Elsevier; 1996.

[5] Weigl J., Yaphe W., Can J of Microbiol. 12 (1966) 939-947.

[6] Le Gall Y., Braud J. P., Kloareg B., Plant Cell Rep 8 (1990) 582-585. 
[7] Ostgaard K., Wangen B. F., Knutsen S. H., Aasen I. M., Enzy Microbial Technol. 5 (1993) 326-333.

[8] Mou H., Jiang X., Guan H., J of Appl Phycol. 15( 2003) 297-303.

[9] Alban S., Schauerte A., Franz G., Carbohydrte Polymer 47 (2002) 267-276.

[10] Arfors K. E., Ley K., J Lab Clinical Medicine 121 (1993) 201-202.

[11] Suzuki N, Kitazato K, Takamatsu J, Saito H. Thrombosis and Haemostasis. 65 (1991)369-373.

[12] Hiroishi S, Sugie K, Yoshida T, Morimoto J, Taniguchi Y, Imai S, Kurebayashi J. Cancer Letters. 167 (2001) 167:145-150.

[13] Caceres P. J., Carlucci M. J., Damonte E. B., Matsuhiro B., Zuniga E. A., Phytochemistry 53 (2000) 81-86.

[14] Knutsen S., Myslabodski D., Larsen B., Usov A Bot Mar 37 (1994) 163-169.

[15] Araki T., Higashimoto Y., Morishita T., Fisheries Science. 65 (1999) 937-942.

[16] Greasham R. L., Biotechnology. In: Rehm HJ, Read G, Puhler A, Stagler P (Eds.), Bioprocessing, vol. 3. VCH Publishers, Inc., New York; 1983.

[17] Thomas D. M., J of Chem Engi. 6 (1977) 180.

[18] Deming S. N., Morgan SL., Elsevier, Oxford; 1987.

[19] Ziayoddin M., Shinde M., Lalitha J., The Bioscan. 4 (2012) 096-095.

[20] Ziayoddin M., Manohar S, Lalitha J., The Bioscan. 5 (2010) 279-283.

[21] Dygert S., Li L. H., Florida D., Thoma J. A., Anal Biochem. 13 (1965) 367-374.

[22] Lowry O. H., Rosebrough N. J., Farr A.L., Randall R. J., J of Biol Chem. 193 (1951) 265-275.

[23] Basawaraj A. K., Manohar S., Lalitha J. Biotechnology and Bioprocess Engineering 18 (2013) 333-341.

[24] Khambhaty Y, Mody K, Jha B., Biotechnol Bioproc Engi. 12 (2007) 668-675.

[25] Sarwar G., Matayoshi S., Oda H., Microbiol Immunol. 31 (1987) 869-877.

[26] Potin P., Sanseau A., Le Gall Y., Rochas C., Kloareg B., Europ J of Biochem. 201 (1991) 241-247.

[27] Mou H. J., Jiang X. L., Jiang X., Guan H. S., J Fish Sci China 9 (2002) 251-254.

[28] Yaphe W., Baxter B., Appl Microbiol 3 (1955) 380-383

[29] Sarwar G., Sakata T., Kakimoto D., Bulletin of the Japanese Society of Scientific Fisheries 49 (1983) 1689-1694.

[30] Mao-hong Zhou, Jian-she Ma, Jun Li, Hai-ren Ye, Ke-xin Huang, Xiao-wei Zhao, Biotechnol Bioproc Engi 13 (2008) 545-551.

[31] McLean M. M., Williamson F. B., Europ J of Biochem. 93 (1979) 553-558.

[32] Lakshmikanth M., Manohar S., Patnakar J., Vaishampayan P., Shouche Y., Lalitha J., World J of Microbiol and Biotechnol. 22 (2006) 531-537. 
[33] Agbo J., Moss M., Canadian J. Microbiol. 115 (1979) 355-368.

[34] Li Y., Chen J., Lun S. Y., Rui X. S., Appl Microbiol and Biotechnol. 55 (2001) 680685.

[35] Tarng Y. S., Juang S. C., Chang C. H., J of Materials Processing Technology 128 (2002) 1-6.

[36] Krishna P. K., Venkata M. S., Sreenivas R. R., Bikas R. P., Sarma P. N., Biochem Engi J. 24 (2005) 17-26.

[37] Sreenivas R. R., Prakasham R. S., Krishna P. K., Rajesham S., Sarma P. N., Venkateswar R. L., Proc Biochem. 39 (2004) 951-956.

[38] Antonopoulos A., Favetta P., Helbert W., Lafosse M., Anal Chem. 77 (2005) 41254136.

[39] Aristotelis A., Hardouin J., Favetta P., Helbert W., Lafosse M., Rapid Communications In Mass Spectrometry 19 (2005) 2217-2226. 